\title{
INFLUENCE OF THE POLYMORPHISM OF APOLIPOPROTEIN E IN CEREBRAL VASCULAR DISEASE
}

\author{
Dorotéia R.S. Souza', Bernadete F. Campos², Érika F. de Arruda², \\ Lucy J. Yamamoto², Daniel M. Trindade ${ }^{3}$, Waldir A. Tognola ${ }^{4}$
}

\begin{abstract}
The genetic heterogeneity of apolipoprotein E (apo E) has been associated with lipid profile and atherothrombotic stroke, however this association remains inconclusive. Objective: To evaluate the relationship between the isoforms of apo $E$ and atherothrombotic stroke, by ascertaining the frequency of its alleles and genotypes associated with the lipid profile in patients with stroke. Method: A total of 207 individuals were divided into two groups, consisting of 107 patients with stroke and 100 individuals without clinical symptoms of the disease. Blood samples were taken from patients and controls for molecular investigation of the apo $E(\varepsilon 2, \varepsilon 3$ and $\varepsilon 4$ alleles) for the analysis of the lipid profile. Results: The $\varepsilon 3$ allele was the most common and its prevalence was significantly higher in patients $(0.93)$ compared to the controls $(0.86 ; p=0.024)$. The $\varepsilon 2$ allele was rarely seen specifically in patients $(0.02$ versus 0.05 in controls, $p=0.191)$. The $\varepsilon 4$ allele was not associated with stroke showing a reduced frequency in patients $(0.05)$ when compared to controls $(0.09 ; p=0.011)$. Although higher average levels of lipid profile were found in patients when compared to controls, with statistical significance for the values of total cholesterol (TC) $(203.6 \mathrm{mg} / \mathrm{dL} \pm 57.98$ and $181.9 \mathrm{mg} / \mathrm{dL} \pm 68.47$ respectively; $p=0.003)$ and lowdensity lipoprotein cholesterol (LDLc) $(131.4 \mathrm{mg} / \mathrm{dL} \pm 52.60$ and $116 \mathrm{mg} / \mathrm{dL} \pm 56.38$, respectively; $p=0.014)$, these were independent of the presence of the $\varepsilon 4$ allele. In control group the higher TC and LDLc values occurred in the absence of the $\varepsilon 4$ allele, confirming the conflicting effect of the alleles of apo $E$ on the plasmatic lipids and atherothrombotic stroke. Conclusion: The isoforms of apo $E$ cannot be regarded as an isolated risk factor for stroke and do not show association with lipid profile in this study.
\end{abstract}

KEY WORDS: stroke, apolipoprotein E, atheromathosis, lipid profile.

\section{Influência do polimorfismo da apolipoproteína $E$ na doença cerebrovascular}

RESUMO - A heterogeneidade genética da apolipoproteína E (apo E) tem sido associada com o perfil lipídico e acidente vascular cerebral aterotrombótico (AVC at); no entanto, esta associação permanece inconclusiva. Objetivo: Avaliar a relação entre as isoformas da apo E e o AVC at pela determinação da frequência de seus alelos e genótipos, associados ao perfil lipídico, em pacientes com a doença. Método: Foram estudados 207 indivíduos distribuídos em 2 grupos, consistindo de 107 pacientes com AVC e 100 indivíduos sem sintomas clínicos da doença. Amostras de sangue periférico foram obtidas de pacientes e controles para investigação molecular da apo E (alelos $\varepsilon 2$, ع3 e $\varepsilon 4$ ) e para análise do perfil lipídico. Resultados: 0 alelo $\varepsilon 3$ foi o mais comum e sua prevalência foi significantemente mais elevada em pacientes $(0,93)$ comparada com controles $(0,86 ; p=0,024)$. 0 alelo $\varepsilon 2$ foi raramente encontrado, especialmente em pacientes $(0,02$ versus 0,05 em controles; $p=0,191)$. A presença do alelo $\varepsilon 4$ não foi associada com AVC, apresentando frequência reduzida em pacientes $(0,05)$ quando comparada com controles $(0,09 ; p=0,011)$. Apesar de níveis médios elevados do perfil lipídico terem sido encontrados em pacientes quando comparados com controles, com significância estatística para valores de colesterol total (CT) $(203,6 \mathrm{md} / \mathrm{dL} \pm 57,98$, e $181,9 \mathrm{mg} / \mathrm{dL} \pm 68,47$, respectivamente; $p=0,003)$ e colesterol de baixa densidade ( $L D L c)(131,4 \mathrm{mg} / \mathrm{dL} \pm 52,60$ e $116 \mathrm{mg} / \mathrm{dL} \pm 56,38$, respectivamente; $p=0,014)$, esses resultados se mostraram independentes da presença do alelo $\varepsilon 4$. No grupo controle, os valores mais elevados de CT e LDLC ocorreram na ausência do alelo $\varepsilon 4$, confirmando o efeito conflitante dos alelos da apo $\mathrm{E}$ sobre os lipídios plasmáticos e sobre o AVC at. Conclusão: As isoformas da apo E não podem ser consideradas fator de risco isolado para AVC at e não mostram associação com o perfil lipídico neste estudo.

PALAVRAS-CHAVE: acidente vascular cerebral, apolipoproteína E, ateromatose, perfil lipídico.

Departamentos de Biologia Molecular e de Ciências Neurológicas da Faculdade de Medicina de São José do Rio Preto (FAMERP), São José do Rio Preto SP, Brasil: 'Professora Doutora em Genética; ${ }^{2}$ Médico Residente; ${ }^{3}$ Biólogo, pós-graduando do Departamento de Genética Molecular da Universidade de São Paulo (USP), Ribeirão Preto; ${ }^{4}$ Professor Adjunto Doutor do Departamento de Ciências Neurológicas. Este estudo recebeu auxílio da FAPESP.

Received 6 May 2002, received in final form 9 September 2002. Accepted 14 September 2002. 
Stroke is one of the most common causes of death in the industrialized countries and it affects the population by inflicting physical, emotional and economic injury to patients with serious consequences on their families and on the public health system. Studies have been searching for ways of controlling and preventing the stroke by investigating risk factors such as smoking, hypertension, dyslipidemia, diabetes and familial history ${ }^{1,2}$. Apolipoprotein E (apo E), associated with coronary arterial disease (CAD) and with the diversity of the serum lipid profile among individuals ${ }^{3-6}$, has also been related as a risk factor for stroke ${ }^{7,8}$ as it exerts an important role in the modulation of the atherogenic lipoproteins. The APOE gene, mapped on chromosome 19, exhibits at one unique locus three principal alleles $\varepsilon 2, \varepsilon 3$ and $\varepsilon 4$ and their frequencies in Caucasian populations are estimated at $8 \%, 77 \%$ and $15 \%$ respectively. The most common phenotype $E 3 / 3$ is represented in $60 \%$ of the population followed by E3/4 (22\%), E2/3 (12\%), E4/4 (3\%), E2/4 (2\%) and E2/2 (1\%) ${ }^{9}$. Gender has no influence on the frequency of the alleles of apo $\mathrm{E}^{10}$.

The association between the genetic heterogeneity of apo $E$ and stroke is controversial. Some studies demonstrated a significantly higher frequency of the $\varepsilon 4$ allele in patients with a familial history of stroke, compared to control individuals ${ }^{7,11-13}$. In this case, the etiological role of the $\varepsilon 4$ allele is due to its association with arterosclerosis. However, other studies deny the existence of any relationship between apo $\mathrm{E} 4$ and the risk for stroke ${ }^{14-17}$. Therefore, the contribution of apo $E$ in the outcome of the disease remains inconclusive, with the absence of any clear result in the Brazilian population.

The aim of this study was to verify the relationship between the isoforms of apo $E$ and atherothrombotic stroke, by ascertaining the frequency of its alleles and genotypes associated with the lipid profile, in patients with clinical manifestations of cerebral atherosclerotic disease.

\section{METHOD}

A total of 207 white individuals, non-related were studied. Among them, 120 (58\%) were male and 87 (42\%) female, with ages greater than 55 years. The individuals were separated into Group 1, consisting of 107 patients with atherothrombotic stroke and an average age of 68.8 \pm 9.17 years; and Group 2, consisting of 100 individuals without clinical symptoms of the disease and a mean age of 69.4 \pm 8.29 years ( $p$ value $=0.6013$ ). The groups were matched by age and gender. The diagnosis of stroke was based on clinical data and in the computed tomographic (CT) scan study. The neurological history and examination included loss of cerebral function, focal signs, with symptoms that lasted more than 24 hours. All the patients undergone a CT scan during the hospitalization, showing areas of low attenuation compatible with the clinical symptoms and signs. The patients were categorized into a possible subtype of stroke based on the Trial of Org 10172 in Acute Stroke Treatment - TOAST ${ }^{19}$, including only large artery artherosclerosis as the cause of ischemic stroke. The subjects with a cardioembolic factor were not included in this study.

The lipid profile included the serum level of total cholesterol (TC), low-density lipoprotein cholesterol (LDLC), highdensity lipoprotein cholesterol (HDLC), very low-density lipoprotein cholesterol (VLDLc), and triglycerides (TG) at the time of hospitalization or immediately after the first consultation in the outpatient clinic.

Molecular investigation of apo $E$ included extraction of the DNA from leukocytes ${ }^{20}$ and amplification of the polymorphic fragment by polymerase chain reaction (PCR). The resulting product was submitted to enzyme digestion using Hha I followed by electrophoresis in $6 \%$ polyacrylamide gel and ethidium bromide stain.

Statistical analysis included the Fisher test, the twotail Mann-Whitney test and odds ratio with a confidence interval $(\mathrm{Cl})$ of $95 \%$. The lipid profile and its association with the genotypes of apo $E$, related to the presence of $\varepsilon 4$ allele, were analyzed in both groups. An error $\alpha 5 \%$ was admissible with a significance level for $p$ value $\leq 0.05$.

Informed consent was obtained from all subjects, and the study was approved by the Institution's Research Ethical Committee.

\section{RESULTS}

The allelic and genotypic frequencies for apo $E$ and serum lipid levels were evaluated in 107 patients with stroke and 100 controls. Table 1 shows the distribution of the apo E polymorphism in relation to the presence of alleles and genotypes in both groups. The prevalence of the $\varepsilon 3$ allele was significantly higher in the patients (0.93) compared with the controls $(0.86 ; p=0.029)$. The $\varepsilon 4$ allele had a significantly higher frequency in the controls (0.09), compared with the patients $(0.046 ; p=0.016)$. The $\varepsilon 3 / \varepsilon 3$ genotype was significantly more frequent in patients $(87 \%)$ than in the control group $(74 \%)$, $(p=0.02)$, but the frequency of $\varepsilon 3 / \varepsilon 4$ in controls $(16 \%)$ and in patients $(7 \%)$ was not statistically significant $(p=0.08)$. Other genotypes were absent or rarely seen in both groups. Risk factors such as hypertension, smoking and diabetes mellitus were observed in patients at rates of $81 \%, 43 \%$ and $20 \%$ and in the control group at $39 \%, 49 \%$ and $13 \%$, respectively.

The lipid profile remained within the desired limits in both groups (Table 2), although significantly higher levels of TC and LDLC were observed in patients 
Table 1. Allelic and genotypic frequencies for apolipoprotein E in patients and controls.

\begin{tabular}{cccccc}
\hline & \multicolumn{2}{c}{ Patients } & \multicolumn{2}{c}{ Controls } & \\
Alleles & $\mathrm{N}$ & Frequency & $\mathrm{N}$ & Frequency & $\mathrm{p}^{*}$ \\
\hline$\varepsilon 2$ & 5 & 0.02 & 10 & 0.05 & $0.1916 \mathrm{NS}$ \\
$\varepsilon 3$ & 199 & 0.93 & 172 & 0.86 & $0.0243 \mathrm{~S}$ \\
$\varepsilon 4$ & 10 & 0.05 & 18 & 0.09 & $0.0116 \mathrm{~S}$ \\
Total & 214 & 1.00 & 200 & 1.00 & \\
Genotypes & $\mathrm{N}$ & $\%$ & $\mathrm{~N}$ & $\%$ & $\mathrm{p}$ \\
$\varepsilon 2 / \varepsilon 2$ & 0 & 0 & 0 & 0 & $\mathrm{NS}$ \\
$\varepsilon 3 / \varepsilon 2$ & 5 & 5 & 8 & 8 & $0.3979 \mathrm{NS}$ \\
$\varepsilon 3 / \varepsilon 4$ & 0 & 0 & 2 & 2 & $0.2346 \mathrm{NS}$ \\
$\varepsilon 3 / \varepsilon 3$ & 93 & 87 & 74 & 74 & $0.0229 \mathrm{~S}$ \\
$\varepsilon 3 / \varepsilon 4$ & 8 & 7 & 16 & 16 & $0.0814 \mathrm{NS}$ \\
$\varepsilon 4 / \varepsilon 4$ & 1 & 1 & 0 & 0 & \\
Total & 107 & 100 & 100 & 100 & \\
\hline
\end{tabular}

*Fisher Test; NS, not significant; S, significant; N, number of individuals.

Table 2. Lipid profile of patients with cerebral vascular disease and controls.

\begin{tabular}{lcccccc}
\hline \multirow{2}{*}{ Lipid profile $(\mathrm{mg} / \mathrm{dL})$} & \multicolumn{2}{c}{ Patients $(\mathrm{N}=107)$} & \multicolumn{2}{c}{ Controls $(\mathrm{N}=100)$} & $\mathrm{p}^{*}$ & \\
& Mean & SD & Mean & SD & & \\
\hline TC & 203.6 & 57.98 & 181.9 & 68.47 & 0.003 & $\mathrm{~S}$ \\
LDLC & 131.4 & 52.60 & 116.0 & 56.38 & 0.0143 & $\mathrm{~S}$ \\
HDLC & 47.8 & 15.90 & 42.0 & 16.92 & 0.3928 & $\mathrm{NS}$ \\
VLDLC & 30.0 & 32.95 & 25.8 & 12.89 & 0.3738 & $\mathrm{NS}$ \\
TG & 137.3 & 69.90 & 125.5 & 66.30 & 0.1401 & $\mathrm{NS}$ \\
\hline
\end{tabular}

*Mann-Whitney Test; N, number of individuals; SD, standard deviation; NS, not significant; S, significant; TC, total cholesterol; LDLc, low density lipoprotein cholesterol fraction; HDLc, high density lipoprotein cholesterol fraction; VLDLc, very-low density lipoprotein cholesterol fraction; TG, triglycerides.

(203.6 $\pm 57.98 ; 131.4 \pm 52.6 \mathrm{mg} / \mathrm{dL}$, respectively)

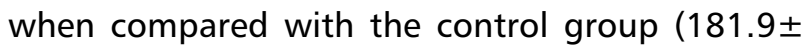
$68.47 ; 116.0 \pm 56.38 \mathrm{mg} / \mathrm{dL}$, respectively) ( $p=0.003$; $p=0.0143$, respectively). However, the comparative study of the lipid profile in relation to the genotyping of apo $E$ revealed similar lipid levels without any significant influence exerted by the $\varepsilon 4$ allele, in patients and controls (Table 3). No significant effect was observed even when only borderline values were analysed with or without the presence of the $\varepsilon 4$ allele (Table 4). In this case, slightly increased TC levels were measured in patients with at least one $\varepsilon 4$ allele $(323.5 \pm 62.93 \mathrm{mg} / \mathrm{dL})$ compared to its absence $(281.1 \pm 28.16 \mathrm{mg} / \mathrm{dL})$, whilst in the control group the opposite was observed $(260.2 \pm 11.53 ; 291.6 \pm$ $67.08 \mathrm{mg} / \mathrm{dL}$, respectively; $\mathrm{p}=0.1336$ ).

Figure 1 demonstrates the effect of the presence and absence of the $\varepsilon 4$ allele on the lipid profile in the study and control groups, assessed as a percentage variation of the average levels when taking into account only borderline values for TC, LDLC, HDLC, and VLDLC. The mean values of TC and LDLC for the patients increased in the presence of $\varepsilon 4$ by $14.9 \%$ and $6.9 \%$, respectively, while in the control group there was a reduction of $10.7 \%$ and $22.3 \%$, respectively. The control group also showed a $3.7 \%$ reduction in HDLc levels.

Odds ratio confirmed that the $\varepsilon 4$ allele did not significantly influence the lipid profile in either of the groups (Table 5).

\section{DISCUSSION}

In this study the presence of the $\varepsilon 4$ allele was not associated with stroke showing a reduced frequency in patients compared to control individuals. Although higher average levels of the lipid profile were seen 
Table 3. Mean values for the lipid profile in the presence or absence of the $\varepsilon 4$ allele for apolipoprotein $E$ in patients and controls.

\begin{tabular}{ccccccc}
\hline PL & \multicolumn{2}{c}{ Patients } & \multicolumn{4}{c}{ Controls } \\
$(\mathrm{mg} / \mathrm{dL})$ & With $\varepsilon 4$ & Without $\varepsilon 4$ & $\mathrm{p}^{*}$ & With $\varepsilon 4$ & Without $\varepsilon 4$ & $\mathrm{p}^{*}$ \\
\hline TC & 207.22 & 203.32 & 0.9463 & 175.06 & 183.44 & 0.7399 \\
& $(\mathrm{~N}=9)$ & $(\mathrm{N}=98)$ & $\mathrm{NS}$ & $(\mathrm{N}=18)$ & $(\mathrm{N}=82)$ & $\mathrm{NS}$ \\
LDLC & 138.56 & 130.77 & 0.9910 & 109.17 & 117.49 & 0.8051 \\
& $(\mathrm{~N}=9)$ & $(\mathrm{N}=98)$ & $\mathrm{NS}$ & $(\mathrm{N}=18)$ & $(\mathrm{N}=82)$ & $\mathrm{NS}$ \\
HDLc & 43.89 & 44.84 & 0.8487 & 46.022 & 41.43 & 0.3940 \\
& $(\mathrm{~N}=9)$ & $(\mathrm{N}=98)$ & $\mathrm{NS}$ & $(\mathrm{N}=18)$ & $(\mathrm{N}=82)$ & $\mathrm{NS}$ \\
VLDLC & 25.22 & 30.43 & 0.6575 & 21.39 & 26.77 & 0.2757 \\
& $(\mathrm{~N}=9)$ & $(\mathrm{N}=98)$ & $\mathrm{NS}$ & $(\mathrm{N}=18)$ & $(\mathrm{N}=82)$ & $\mathrm{NS}$ \\
TG & 124.11 & 138.53 & 0.5482 & 99.44 & 131.18 & 0.1671 \\
& $(\mathrm{~N}=9)$ & $(\mathrm{N}=98)$ & $\mathrm{NS}$ & $(\mathrm{N}=18)$ & $(\mathrm{N}=82)$ & $\mathrm{NS}$ \\
\hline
\end{tabular}

*Mann-Whitney Test; N, number of individuals; NS, not significant; S, significant; TC, total cholesterol; LDLC, low density lipoprotein cholesterol fraction; HDLc, high density lipoprotein cholesterol fraction; VLDLc, verylow density lipoprotein cholesterol fraction; TG, triglycerides.

Table 4. Mean values for the lipid profile considering only the altered levels of total cholesterol (TC>240mg/dL), LDLc (>160mg/dL), HDLc (<40mg/dL), VLDLc (>35mg/dL) and TG (>200mg/dL).

\begin{tabular}{|c|c|c|c|c|c|c|}
\hline \multirow{2}{*}{$\begin{array}{c}\mathrm{PL} \\
(\mathrm{mg} / \mathrm{dL})\end{array}$} & \multicolumn{2}{|c|}{ Patients } & \multicolumn{4}{|c|}{ Controls } \\
\hline & With $\varepsilon 4$ & Without $\varepsilon 4$ & $p^{*}$ & With $\varepsilon 4$ & Without $\varepsilon 4$ & $p^{*}$ \\
\hline TC & 323 & 281 & 0.2414 NS & 260,2 & 291,6 & $0.1336 \mathrm{NS}$ \\
\hline SD & $\begin{array}{l}62.93 \\
(N=2)\end{array}$ & $\begin{array}{c}28.16 \\
(N=27)\end{array}$ & & $\begin{array}{l}11.53 \\
(N=4)\end{array}$ & $\begin{array}{c}67.08 \\
(N=15)\end{array}$ & \\
\hline LDLC & 213 & 199 & 0.8357 NS & 184,3 & 225,5 & $0.1011 \mathrm{NS}$ \\
\hline SD & $\begin{array}{l}72.86 \\
(N=3)\end{array}$ & $\begin{array}{c}28.26 \\
(N=27)\end{array}$ & & $\begin{array}{l}20.55 \\
(\mathrm{~N}=3)\end{array}$ & $\begin{array}{c}50.62 \\
(N=12)\end{array}$ & \\
\hline VLDLC & 31 & 31 & 0.4822 NS & 26,0 & 27 & $0.8693 \mathrm{NS}$ \\
\hline$S D$ & $\begin{array}{c}1.53 \\
(N=3)\end{array}$ & $\begin{array}{c}6.51 \\
(N=45)\end{array}$ & & $\begin{array}{c}8.40 \\
(N=7)\end{array}$ & $\begin{array}{c}8.82 \\
(N=36)\end{array}$ & \\
\hline HLDLC & 44 & 46 & 0.6895 NS & 45 & & \\
\hline SD & $\begin{array}{l}11.31 \\
(\mathrm{~N}=2)\end{array}$ & $\begin{array}{c}10.59 \\
(N=25)\end{array}$ & & $\begin{array}{c}9.8 \\
(\mathrm{~N}=0)\end{array}$ & $(\mathrm{N}=23)$ & \\
\hline TG & 263 & 263 & & 251 & & \\
\hline$S D$ & $(\mathrm{~N}=1)$ & $\begin{array}{c}49.90 \\
(N=16)\end{array}$ & & $(\mathrm{N}=0)$ & $\begin{array}{c}50.63 \\
(N=15)\end{array}$ & \\
\hline
\end{tabular}

*Mann-Whitney Test; N, number of individuals; SD, Standard Deviation; NS, not significant; S, significant; TC, total cholesterol; LDLc, low density lipoprotein cholesterol fraction; HDLc, high density lipoprotein cholesterol fraction; VLDLc, very-low density lipoprotein cholesterol fraction; TG, triglycerides.

in patients when compared to controls, with statistic significance for the values of TC and LDLC, these were independent of the presence of the $\varepsilon 4$ allele. The $\varepsilon 2$ allele was rarely found specifically in patients, suggesting a possible protecting effect ${ }^{14}$.
The role of the $\varepsilon 4$ allele in the pathogenesis of atherothrombotic stroke is still controversial, with inconsistent results in the Brazilian population. In this study, the $\varepsilon 4$ allele was observed with a significantly reduced frequency in patients (0.05) when 


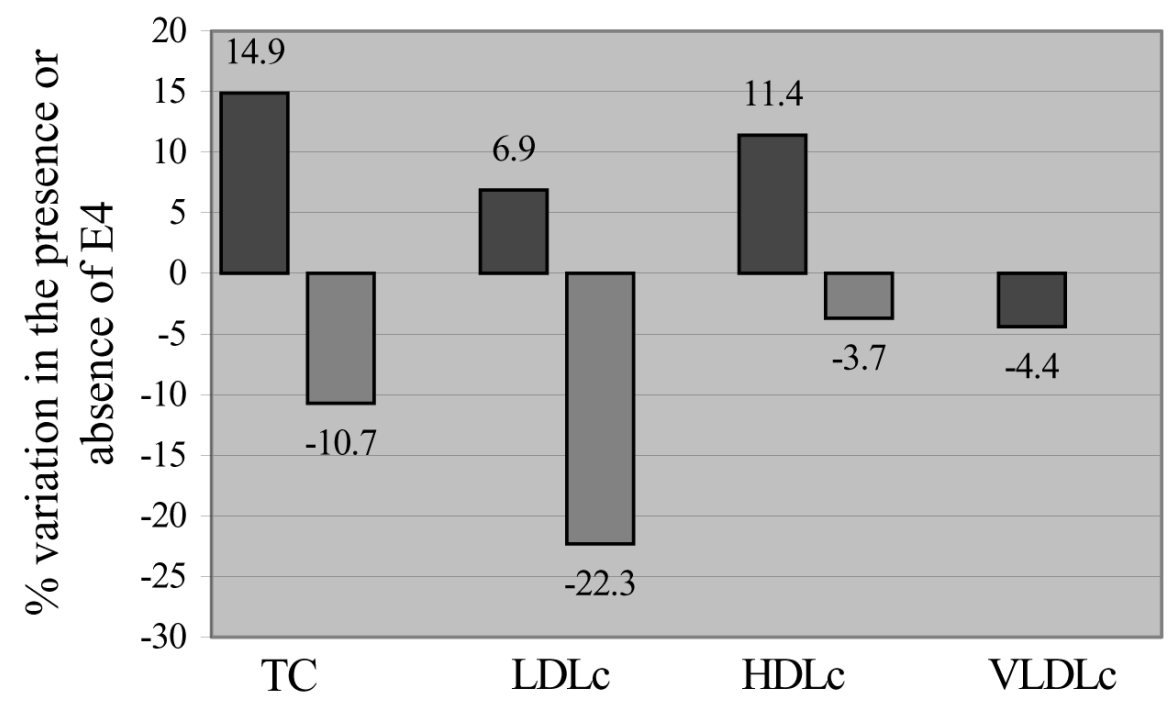

Patient

Control

\section{Lipid profile}

Fig 1. Effect of the $\varepsilon 4$ allele for Apolipoprotein $E$ on the levels of total cholesterol (TC) and lipoprotein cholesterol fractions of low (LDLC), high (HDLC) and very low (VDLC) density, considering the variation of the lipid profile in the presence or absence of the $\varepsilon 4$ allele in patients and controls.

Table 5. Odds ratio for the lipid profile according to the frequency of the $\varepsilon 4$ allele for apolipoprotein $E$ in patients and controls.

\begin{tabular}{lccccc}
\hline Individual & \multicolumn{5}{c}{ Odds Ratio $(\mathrm{Cl})$} \\
& $\mathrm{TC}$ & LDLc & HDLc & VLDLc & TG \\
\hline Patients & 0.75 & 1.25 & 1.69 & 5.83 & 0.64 \\
$\mathrm{Cl}$ & $(0.1467-3.847)$ & $(0.2921-5.35)$ & $(0.4015-7.182)$ & $(0.1625-4.285)$ & $(0.0748-5.485)$ \\
Controls & 1.27 & 1.17 & 1.23 & 0.01 & 0.12 \\
$\mathrm{Cl}$ & $(0.3676-4.430)$ & $(0.2926-4.65)$ & $(0.4332-3.491)$ & $(0.0039-1.183)$ & $(0.0067-2.062)$ \\
\hline
\end{tabular}

$\mathrm{Cl}$, confidence interval; TC, total cholesterol; LDLc, low density lipoprotein cholesterol fraction; HDLc, high density lipoprotein cholesterol fraction; VLDLc, very low density lipoprotein cholesterol fraction; TG, triglycerides.

compared to controls (0.09). In others studies an association was seen between the $\varepsilon 4$ allele and stroke $^{7,11,12}$. McCarron et al. ${ }^{7}$ observed in a metaanalytical study, a higher prevalence of the $\varepsilon 4$ allele in patients with ischemic stroke compared to a control group ( 0.14 versus 0.09 ; odds ratio of $1.68-\mathrm{Cl}$ $95 \%$ : range $1.36-2.09 ; p<0.001)$. Margaglione et al. ${ }^{12}$ detected a significantly higher frequency of the $\varepsilon 4$ allele in patients with a familial history of stroke (0.18) compared to individuals without this familial history (0.07) and healthy individuals (0.09). However other authors have also discarded the relationship between apo E4 and risk of stroke $6,14,15$. On the other hand, it is possible that the $\varepsilon 4$ allele carriers be more susceptible to complications, increasing the probability of an earlier mortality.

In this study the low frequencies of the $\varepsilon 2$ and $\varepsilon 4$ alleles in both patients and controls with ages of approximately 70 years, determined the prevalence of the $\varepsilon 3$ allele, which was significantly more common in patients (93\%) compared to controls (86\%). These frequencies were more elevated compared to Caucasian population and more consistent to Asian samples $(85 \%)^{4}$. In populations, the apo E polymorphism explains the variation in LDLc plasmatic levels ${ }^{10,22}$. 
The association between the apo E polymorphism and atherosclerosis was first described by Utermann et al. ${ }^{23}$ in studies of patients with type III hyperlipoproteinemia, E2/2 genotypes and early onset of stroke. In the Finnish population the high frequency of E4, low frequency of E2 and the exceptionally high rate of stroke in the country, support a suggested association between this disease and the apo $\mathrm{E}$ phenotypes. In Finland, 34\% of the individuals have the E4/4 or E3/4 phenotypes. Thus, the phenotypes which express the apo E4, associated with a traditional Finnish diet rich in saturated fats and cholesterol, can induce hyperlipoproteinemia especially in rural areas where the saturated fat proportion in the diet is considerably higher ${ }^{24}$.

In this study, an increased effect of the $\varepsilon 4$ allele was only observed when considering patients with borderline values. These patients presented on average increases of about $15 \%(42 \mathrm{mg} / \mathrm{dL})$ and $7 \%$ $(14 \mathrm{mg} / \mathrm{dL})$ of TC and LDLc levels, respectively. But these values were not considered significant in relation to patients without the $\varepsilon 4$ allele. However, epidemiological studies have alerted of the benefits of a reduction in plasmatic cholesterol levels, as an effective intervention to decrease the morbidity and mortality rates caused by cardiovascular disease. Gould et al. ${ }^{9}$ in a meta-analytical study revealed that for every $10 \%$ decrease in plasmatic cholesterol levels there was a $15 \%$ reduction in the total risk of mortality by cardiovascular disease and an $11 \%$ reduction in the total risk of death. This suggests that, although there was a low representation in this study group, the $\varepsilon 4$ allele could have an influence in the morbimortality rate, principally of patients with atherothrombotic stroke and an increased lipid profile.

The effect on the TC and LDLC values in the patients with at least one $\varepsilon 4$ allele, could result from its interaction with other atherogenic risk factors, such as hypertension, smoking and diabetes observed in $81 \%, 43 \%$ and $20 \%$ of the patients, respectively. In this way, the results can indicate that these risk factors, associated with the genesis of stroke, can compromise the evaluation of the apo E polymorphism as a risk factor for this disease.

On the other hand, in the control group the higher TC and LDLc values occur in the absence of the $\varepsilon 4$ allele, confirming its non-significant effect in these individuals with a mean age of nearly 70 years old and without clinical symptoms of stroke. In reality, the effect of the alleles of apo $E$ on the plasmatic lipids is still conflicting. There is a reference of an important correlation between the $\varepsilon 2$ allele and the plasmatic lipid levels in an ageing multi-ethnic population, while the $\varepsilon 4$ allele remains without expression $^{25}$ and it is not associated with an altered lipid profile in a rural North American population ${ }^{26}$.

Due to the similarities of the risk factors for atherothrombotic cerebral stroke and coronary disease, in which the lipid profile is an independent risk factor, a positive association between apo E4 with a well-known function on the lipid metabolism and cerebral infarction would be expected. This was not observed in this study. It is possible that the role of apo $E$ in cerebral infarction is not etiological but that its genotype influences the degree of neuronal degradation after a cerebral event as was demonstrated by Tomimoto, et al. ${ }^{27}$ Furthermore, studies in younger populations could clarify the effect of the apo E polymorphism with greater reliability. Ferruci et al. ${ }^{14}$ detected a lower risk of stroke in under 80 years old individuals who were carriers of the $\varepsilon 2$ allele which was not seen in an older group.

It is evident that a complex disease such as stroke is determined by multiple factors, both genetic and environmental. This makes it improbable that a single gene locus can identify a subset of individuals susceptible to the disease. The recent increase in life expectancy encourages the investigation of other risk factors of cerebral-vascular disease with the view of precocious intervention to control morbi-mortality associated with age.

\section{CONCLUSION}

In conclusion, this study shows that the $\varepsilon 4$ allele, with a reduced frequency particularly in patients suffering from stroke, can not be regarded as an isolated risk factor for this disease. Variations in the lipid profile apparently demonstrate independence from apo E, although, increased levels of TC, LDLC and also HDLc appear to be poorly associated with $\varepsilon 4$ allele in the patients, which needs further investigation in this subgroup.

Acknowledgments - The authors thank Dr. Moacir Fernandes de Godoy for his valuable contribution in the statistical analysis, Marcela Augusta Pinhel for her graphic design and David Andrew Hewitt for preparing the English manuscript.

\section{REFERENCES}

1. Adams RD, Victor M. Doenças Cerebrovasculares. In Adams RD, Victor M Princípios de neurologia, 5.Ed. Rio de Janeiro: Nueva Editorial Interamericana; 1996:481-536.

2. Saposnik G, Terzaghi MA. Genetical aspects in cerebrovascular disease. Rev Neurol 1999;28:1098-104.

3. Cumming AM, Robertson F. Polymorphism at the apo E locus in relation to risk of coronary disease. Clin Genet 1984;25:310-313. 
4. Lenzen HJ, Assmann G, Buchwalsky R, Schulte H. Association of apolipoprotein E polymorphism, low density lipoprotein, and coronary artery disease. Clin Chem 1986;32:778-781.

5. Kuusi T, Nieminen MS, Ehnholm C, et al. Apolipoprotein E polymorphism and coronary artery disease: angiographically verified coronary patients. Arteriosclerosis 1989;9:237-241.

6. Marin DB, Breur B, Marin ML, et al. The relationship between apolipoprotein E, dementia, and vascular illness. Atherosclerosis 1998; 140:173-180.

7. McCarron MO, Delong D, Alberts MJ. Apolipoprotein E genotype as a risk factor for ischemic cerebrovascular disease: a meta-analysis. Neurology 1999;53:1308-1311.

8. DeCarli C, Reed T, Miller BL, Wolf P, Swan GE, Carmelli D. Impact of apolipoprotein $\mathrm{E}$ epsilon 4 and vascular disease on brain morphology in men from the NHLBI twin Study. Stroke 1999;8:1548-1553.

9. Gould AL, Rossouw JE, Santanello NC, Heyse JF, Fuberg CD. Cholesterol reduction yelds clinical benefit: impact of statin trials. Circulation, 1998;17;97:946-952.

10. Wu LH, Wu JT, Hopkins P. Apolipoprotein E: laboratory determinations and clinical significance. In Rifai N, Warnick GH, Dominiczak MH (eds) Handbook of lipoprotein testing. Washington: AACC Press, 1997:598.

11. Pedro-Botet J, Sentì M, Nogues X, et al. Lipoprotein and apolipoprotein profile in men with ischemic stroke: role of lipoprotein (a), triglyceride-rich lipoproteins and apoprotein E polymorphism. Stroke 1992; 23:1556-1562.

12. Margaglione M, Seripa D, Gravina C, et al. Prevalence of apoprotein E in healthy subjects and survivors of ischemic stroke. Stroke 1998;29:399-403.

13. Peng DK, Zhao SP, Wang JL. Lipoprotein (a) and apolipoprotein E epsilon 4 as independent risk factors for ischemic stroke. J. Cardiovasc Risk 1999;6:1-6.

14. Ferrucci L, Guralnik JM, Pahor M, et al. Apolipoprotein E $\varepsilon 2$ allele and risk of stroke in the older population. Stroke 1997;28:2410-2416.

15. Nakata $Y$, Katsuya T, Rakugi H, Takami S, Noriyuki S, Kamide K Polymorphism of angiotensin converting enzyme, angiotensinogen, and apolipoprotein Egenes in a Japanese population with cerebrosvacular disease. Am J Hypert 1997;10:1391-1395.
16. Cao W, Chen F, Teng L, Wang S, Fu S, Zang G. The relationship between apolipoprotein $\mathrm{E}$ gene polymorphism and coronary heart disease and arteriosclerotic cerebral infarction. Chung Hua IHsueh IChuan Hsueh Tsa Chih 1999;4:249-251.

17. Catto AJ, Mc Cormack LJ, Mansfield MW, et al. Apolipoprotein E polymorphism in cerebrovascular disease. Acta Neurol Scand 2000;101:399-404.

18. Sociedade Brasileira de Cardiologia. $2{ }^{\circ}$ Consenso Brasileiro sobre Dislipidemias Arq Bras Card 1996;67:3.

19. Adams HP Jr, Bendixen BH, Kappelle LJ, et. al. Classification of subtype of acute ischemic stroke: definitions for use in a multicenter clinical trial. Stroke 1993;24:35-41.

20. Gustincich S, Manfioletti G, Del San G, Schnider C. A fast method for high-quality genomic DNA extraction from whole human blood. BioTech 1991;11:298-301.

21. McCarron MO, Muir KW, Nicoll JA, et al. Prospective study of apolipoprotein $\mathrm{E}$ genotype and functional outcome following ischemic stroke. Arch Neurol 2000;57:1480-1484.

22. Guilling H, Kontula K, Miettinen TA. Cholesterol absorption and metabolism and LDL cinetics in healthy men with different apoprotein E phenotypes and apoprotein B Xba I and LDL receptor Pvu II genotypes. Arterioscler Thromb Vasc Biol 1995;15:208-213.

23. Utermann $G$, Jaeschke M, Menzel J. Familial hyperlipoproteinemia type III: deficiency of a specific apolipoprotein (Apo E3) in very low density lipoproteins. FEBS 1975;56:352-355.

24. Lehtimaki T, Moilanen T, Nikkari T, et al. Regional differences in apolipoprotein E polymorphism in Finland. Ann Med 1991;23:61-66.

25. Pablo-Mendez, Mayeux R, Nagai C, et al. Association of apo E polimorphism with plasma levels in multiethnic elderly population. Arterioscl Thromb Vasc Biol 1997;17:3534-3541.

26. Aguilar CA, Talavera G, Ordovas JM, et al. The apolipoprotein E4 allele is not associated with an abnormal lipid profile in a native american population following its traditional lifestyle. Atherosclerosis 1999;142:409-414.

27. Tomimoto H, Akiguchi I, Suenaga E, Wakita H, Nakamura S, Kimura J, et al. Immunohistochemical study of apolipoprotein $\mathrm{E}$ in human cerebrovascular white matter lesions. Acta Neuropathol 1995; 90:608-614. 